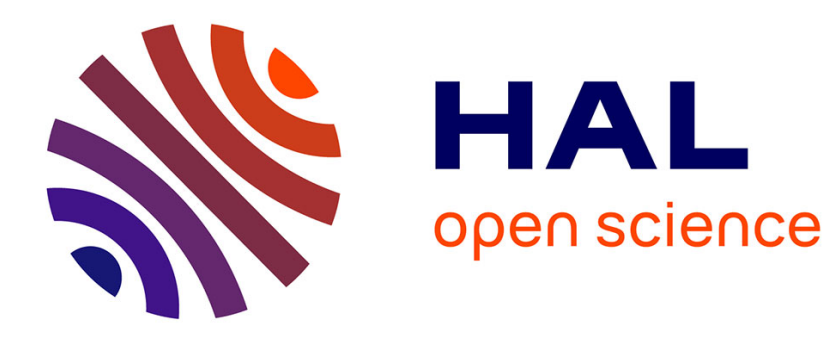

\title{
The ineffectiveness of hermeneutics. Another Augustine's legacy in Gadamer
}

\author{
Alberto Romele
}

\section{To cite this version:}

Alberto Romele. The ineffectiveness of hermeneutics. Another Augustine's legacy in Gadamer. International Journal of Philosophy and Theology, 2015, 75 (5), pp.422-439. 10.1080/21692327.2015.1027789 . hal-01303281

\section{HAL Id: hal-01303281 \\ https://hal.science/hal-01303281}

Submitted on 17 Apr 2016

HAL is a multi-disciplinary open access archive for the deposit and dissemination of scientific research documents, whether they are published or not. The documents may come from teaching and research institutions in France or abroad, or from public or private research centers.
L'archive ouverte pluridisciplinaire HAL, est destinée au dépôt et à la diffusion de documents scientifiques de niveau recherche, publiés ou non, émanant des établissements d'enseignement et de recherche français ou étrangers, des laboratoires publics ou privés. 


\title{
The Ineffectiveness of Hermeneutics. Another Augustine's Legacy in Gadamer
}

\author{
Alberto Romele \\ Institute of Philosophy, University of Porto \\ COSTECH Laboratory, University of Technology of Compiègne
}

\begin{abstract}
This article builds on Gadamer's rehabilitation of the Augustinian concept of inner word (verbum in corde). Unlike most interpretions, the thesis is that the Augustinian inner word does not show the potentialities, but rather the ineffectiveness of ontological hermeneutics. In the first section, it is argued that for the later Augustine the verbum in corde is the consequence of a Word- and Truth- event. In the second section, the author suggests that Gadamer has properly understood the verbum in corde as a matter of faith. In the third section, it is shown that Gadamer has found in the notion a paradigm for his philosophical and theological insights. Concerning the former, he has always been fascinated by the evenemential character of the 'second' Heidegger's thought. Concerning the latter, Gadamer has explicitly accused Bultmann's demythologization of being 'human, all too human', and he has implicitly praised Barth's dialectical theology.
\end{abstract}

Keywords: verbum in corde, hermeneutics, later Augustine, Gadamer, Grace

\section{Introduction}

This article builds on the chapter Sprache und verbum of Wahrheit und Methode, in which Gadamer rehabilitates the notion of 'inner word', and opposes it to the 'forgetfulness of language (Sprachvergessenheit)' that Plato would have inaugurated with the Cratylus. My hypothesis, as Jean Grondin ${ }^{1}$ and other scholars ${ }^{2}$ have already stated, is that the rehabilitation of the notion of 'inner word' can be seen as a paradigm for all hermeneutics aiming at truth and universality. Together with the most part of interpreters, moreover, I share both the idea that, despite vague references, ${ }^{3}$ Augustine of Hippo is at the core of Gadamer's reflections, and the idea that the verbum in corde (word in the heart) is a privileged point of view to test the whole of ontological hermeneutics' tradition.

However, contrary to Grondin and most interpretations, my thesis is that the Augustinian inner word does not show the potentialities, but rather the ineffectiveness of this tradition. In Gadamer's perspective, the verbum in corde is the consequence of a 'hermeneutical experience', and this is defined as a radically disorientating truth- and word- event: 'Strictly speaking', Gadamer says, 'we cannot have the same [hermeneutical] experience twice. It is true, of 
course, that part of the nature of experience is to be continually confirmed [...]. But it is no longer a [hermeneutical] experience when it is repeated and confirmed. ${ }^{4}$ The hermeneutical experience, than, has not much to do with Aristotle's $\varepsilon \mu \pi \varepsilon i \rho i ́ \alpha$, nor with Hegel's Erfahrung. According to the former, the universality of the concept is ontologically prior and what concerns him about experience is merely how it contributes to the formation of the concept. According to the latter, experience has the structure of a reversal of consciousness but, in the end, for Hegel, conscious experience should lead to a self-knowledge that no longer has anything other or alien to itself. Rather, the hermeneutical experience is represented by the

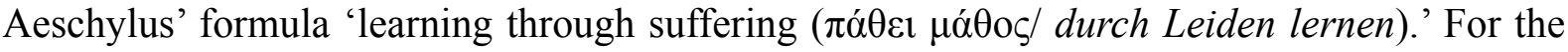
German philosopher, this phrase does not only mean that we become wise through suffering. Aeschylus means more than this: 'He refers to the reason why this is so. What a man has to learn through suffering is not this or that particular thing, but insight into the limitations of humanity, into the absoluteness of the barrier that separates man from the divine. It is ultimately a religious insight $[\ldots] .^{5}$

Hence, the notion of verbum in corde, both for Augustine and Gadamer, does not concern the philosophical explication of the linguistic and semantic structure of the human mind. This is the case, instead, of a long and almost parallel tradition that goes from Aristotle to J. Fodor. Isabelle Koch's recent interpretation of Augustine's inner word is inadequate, insofar it excludes the 'project of the intellectus fidei', to which, as she admits, 'all psychological and cognitive analysis of the De Trinitate conform.' 6 Moreover, the notion of verbum in corde has not much to do with the onto(theo)logical analogy of proportion between the Word in God and the incarnate Word on the one hand, and the inner and outer word in men on the other. Several Greek and Latin Church fathers have used the classical Stoic distinction between

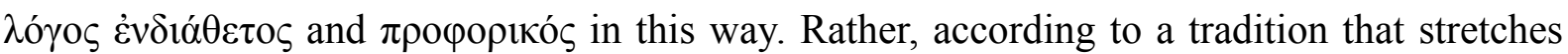
from Paul to the Dialectical Theology of Karl Barth passing through Luther, ${ }^{7}$ the verbum in corde, as thought by the late Augustine and rehabilitated by Gadamer, must be understood as a genuine theological concept. More precisely, the verbum in corde is the consequence of the donum dei, the gratuitous intervention of the grace on men, which is the sole source of good human words and actions. A certain affinity between ontological hermeneutics and Protestant theology in the twentieth century is attested among the scholars. The mutual influence between the earlier Heidegger and Bultmann is well known. Elsewhere, I have demonstrated the analogies between Paul Ricoeur's philosophical and biblical hermeneutics and Gerhard Ebel- 
ing's theological hermeneutics. ${ }^{8}$ Italian interpreter Giovanni Moretto has devoted a book to the religious dimension in Gadamer's philosophy, arguing that there are several affinities between his hermeneutics and Barth's dialectical theology. Now, my hypothesis is precisely that Gadamer's non-philosophical and non-onto(theo)logical - or non-analogical - rehabilitation of the verbum in corde reflects an attitude towards Christology which is rather Barthian.

I will try to demonstrate my thesis in three steps. First of all, I will describe the development of the notion in the Augustinian corpus from the De dialectica to the XV Book of the De Trinitate. Secondly, I will hypothesize if Gadamer has properly understood Augustine's intentions with the use of the notion or rather, if he has betrayed them. Thirdly, I will compare Gadamer's rehabilitation of the notion with his philosophical and theological background.

\section{Augustine's verbum in corde}

Augustine inherits the notion of verbum in corde from two traditions. On one hand, the 'Greek' tradition of Plato, Aristotle and the Stoics. Plato and Aristotle used the concept to give an explication of the discursive thought and its logic and semantic properties. ${ }^{9}$ The Stoics

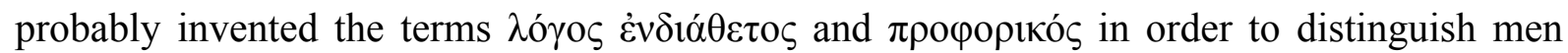
from talking animals such as parrots and blackbirds. ${ }^{10}$ On the other hand, the 'Biblical' or, as Claude Panaccio calls it, the 'Johannine' tradition of several Greek and Latin Church Fathers that used (or refused to use) ${ }^{11}$ the Stoic distinction to defend the Christian dogma of consubstantiality. Yet, through the notion of verbum in corde Augustine also said something new. My thesis here is that the bishop of Hippo has been the first to think of the concept of inner word in light of the doctrine of grace.

According to C. Panaccio, there are three phases in Augustine's use of the concept. Before 395 , the concept is simply absent. In the De dialectica, probably composed in 387, Augustine affirms that 'a word (verbum) is the sign of some thing which can be understood by the hearer when pronounced by the speaker.' ${ }^{\prime 2}$ The verbum is just a means through which the meaning is transmitted. This definition is maintained in the De Magistro, written in 389: 'then a name (nomen) is also a word (verbum) whenever we see that it is uttered by an articulated sound accompanied by some significate. ${ }^{13}$ In this phase, even written words are not properly considered verba, but signorum signa or, at most, signa verborum ${ }^{14}$. The devaluation of the outer word seems radical, and many interpreters have unfortunately reduced the Augustinian theory of language to this early perspective. It must be stressed, however, that already in these early 
writings Augustine developed some notions, which will play an important role in the formation of his concept of inner word. Among them, that of dicibile, which is defined in the De dialectica as what in the word is learned through the mind and not through the ears.

The verbum in corde explicitly appears in a second phase. In the Epistulae ad Romanos incohata expositio, Augustine defines a 'verbum [...] quod corde conceptum (word conceived in the heart). ${ }^{9}$ Speaking, he says, indicates 'not only what we shape with the tongue, but also what is conceived in the heart and manifested through actions.' 16 In the first part of the $D e$ doctrina christiana, than, the bishop of Hippo uses the expression 'verbum quod corde gestamus (the word which we have in our heart)':

\begin{abstract}
Just as when we speak, in order that what we have in our minds may enter through the ear into the mind of the hearer, the word which we have in our hearts becomes an outward sound and is called speech; and yet our thought does not lose itself in the sound, but remains complete in itself, and takes the form of speech without being modified in its own nature by the change: so the Divine Word, though suffering no change of nature, yet became flesh, that He might dwell among us. ${ }^{17}$
\end{abstract}

According to Graziano Ripanti, we assist in this context to a partial rehabilitation of the spoken word. In other words, for him Augustine did not use the distinction between inner and outer word in order to understand Christology, but rather the contrary. ${ }^{18}$ It is precisely in this rehabilitation, he says, that one has to recognize the authentic Augustinian theory of language. Language and communication are not the specific topics of the De Magistro, which are instead at the center of the De doctrina christiana, a sort of manifesto for philosophical hermeneutics. ${ }^{19}$

In a third phase, which starts with the VIII Book of the De Trinitate, probably composed around 417 , the notion of verbum in corde finds its most complete and systematic exposition. In particular, three uses of the notion between Books VIII and XV can be isolated. In Book VIII, Augustine describes a 'verbum apud me (word in me)':

And when indeed I wish to speak of Carthage, I seek within myself what to speak, and I find within myself a notion or image (phantasia) of Carthage [...]. For its word is the image (phantasia) itself of it in my memory, not that sound of two syllables when Carthage is named, or even when that name itself is thought of silently from time to time, but that which I discern in my mind, when I utter that dissyllable with my voice, or even before I utter it. So also, when I wish to speak of Alexandria, which I never saw, an image (phantasma) of it is present with me [...] and this is with me when I wish to speak of it, before I utter with my voice the five syllables which make the name that almost every one knows. ${ }^{20}$ 
The word is considered here as a (sensitive) remembered (phantasia) or imagined (phantas$m a$ ) image. In both cases it is an inner word, i.e. a word independent from every spoken or written word. Yet, this kind of inner word is, for Augustine, still inadequate, because it depends upon the always-changing reality.

In Book IX, the bishop of Hippo describes a verbum, which is 'cum amore notitia (knowledge together with love)': 'A word, then, which is the point we wish now to discern and imitate, is knowledge together with love. Whenever, then, the mind knows and loves itself, its word is joined to it by love.' 21 This kind of inner word is adequate, insofar it does not depend anymore upon exteriority, but upon the autoreflexive capacity of the human soul.

The inner word as cum amore notitia is neither the knowledge of a lower essence, as of the body, nor of a higher, as of God. Rather, this inner word is like the balanced love existing between true friends. Their relation is not similar to that between the color and the colored subject, 'since colored body is a substance, but color is in a substance; but as two friends are also two men, which are substances [...].'22 Nevertheless, for Augustine, even this second kind of inner word does not complete the use of the notion. In Book VIII, discussing the notion of justice, the bishop of Hippo seems surprised by the fact that we can love and know what the righteous man is without being righteous yet:

\footnotetext{
From whence then does he who is not yet righteous know what a righteous man is, and love the righteous man that he may become righteous? [...] But whence do we know what it is to be righteous, even when we are not yet righteous? If we know from without ourselves, we know it by some bodily thing. But this is not a thing of the body. Therefore we know in ourselves what it is to be righteous. For I find this nowhere else when I seek to utter it, except within myself; and if I ask another what it is to be righteous, he seeks within himself what to answer; and whosoever hence can answer truly, he has found within himself what to answer. ${ }^{23}$
}

In other words, according to Augustine there is something in the human soul that constitutes and exceeds the soul itself. French phenomenologist Jean-Luc Marion, reflecting on the concept of memoria in Book X of the Confessiones, has called this foundational instance in man the 'immémorial (immemorial)': 'I live in a place, my self, where I do not find myself, where I am not in my place, where I am not myself: banished from the inside, I am not where I am. ${ }^{24}$ 
Between Book X and XIV, Augustine presents three trinities in the human mind, which reflect with different degrees of perfection the Holy Trinity. These trinities are similar to the three genres of verbum in corde I am describing in this paragraph. In Book XI, a human trinity is presented, made of (1) the perceived body, (2) its impression in the gaze of the perceiving person and (3) the attention of the will, which connects the former to the latter. ${ }^{25}$

This first trinity, still exterior, is replaced with a second trinity in man made of (1) the image of the perceived body in memory, (2) the form that reproduces such an image when the gaze of the subject is oriented to it, and (3) the attention of the will, which once again connects the former to the latter. ${ }^{26}$ The superiority of this trinity compared to the first one is evident, since 'in these three there is no longer any diversity of substance. For neither is the sensible body there, which is altogether distinct from the nature of the living being, nor is the bodily sense there informed so as to produce vision, nor does the will itself perform its office of applying the sense, that is to be informed, to the sensible body, and of retaining it in it when informed. ${ }^{27}$ Nevertheless, even this trinity, through memory contents, maintains a certain link with exteriority. Then, in Book XII, Augustine presents a human trinity, which is completely detached from exteriority, oriented toward the eternal reasons: 'But it is the part of the higher reason to judge these corporeal things according to incorporeal and eternal reasons; [...] But we judge corporeal things from the rule of dimensions and figures, which the mind knows to remain unchangeably. ${ }^{28}$ This third trinity, however, cannot be considered the best image in man of the Holy Trinity since, as Augustine says in Book XV recapitulating the previous analysis, human knowledge is inferior to the wisdom of man, 'which is granted him by God's gift in the partaking of the very God Himself. ${ }^{29}$

In Book XV, the bishop of Hippo returns to speak about the verbum in corde:

Whoever, then, is able to understand a word, not only before it is uttered in sound, but also before the images of its sounds are considered in thought [...] whoever, I say, is able to understand this [word], is able now to see through this mirror and in this enigma some likeness of that Word of whom it is said, In the beginning was the Word, and the Word was with God, and the Word was God. ${ }^{30}$

The two terms 'mirror (spaeculum)' and 'enigma (aenigma)' refer to the First Epistle to the Corinthians $(13,12)$ : 'For now we see in a mirror (per spaeculum), in an enigma (in aenigmitate), but then face to face. Now I know in part, but then I will know fully, even as I was also fully known.' To explain these terms, Augustine uses the expression 'obscura allegoria (ob- 
scure allegory)': 'and hence, as every horse is an animal, but not every animal is a horse, so every enigma is an allegory, but every allegory is not an enigma. What then is an allegory, but a trope wherein one thing is understood from another? [...] but an enigma is, to explain it briefly, an obscure allegory [...]. ${ }^{31}$ As Jean Pépin has stated, allegorical interpretation and allegorical expression represent two opposite intellectual processes. The former consists of the human capacity to go from the first (lower) to the second (higher) meaning of an allegorical expression. The latter corresponds to the creation or identification of signs with a double intentional structure, usually translating into images an abstract knowledge. ${ }^{32}$ The obscure allegory is a particular kind of allegorical expression, whose purpose is not to conduct from the first to the second meaning, but rather to safeguard the distance between them.

According to Tvetan Todorov, the function that Augustine attributes to allegorical expressions changed over the years. ${ }^{33}$ At the time of the first part of the De doctrina christiana, which remained incomplete for almost thirty years, they were considered a sort of stratagem to draw towards the Scriptures the most clever minds, 'for the purpose of preventing a feeling of bore in the intellect, which generally holds in small esteem what is discovered without difficulty.' ${ }^{34}$ The 'traumatic' reception of the Pauline epistles, and in particular of the Pauline doctrine of grace, would have radically affected this first hermeneutical perspective. Italian interpreter Gaetano Lettieri, as Kurt Flash had before him suggested in Logik des Schreckens, individuates in De diversis questionibus ad Simplicianum I, 2 a turning point: 'Therefore we must understand that the law was given not to introduce sin nor to extirpate it, but simply to make it known [...]. Sin cannot be overcome without the grace of God, so the law was given to convert the soul by anxiety about its guilt, so that it might be ready to receive grace.' After this crucial passage, allegorical expression is considered 'a sort of veil, which precludes to natural intelligence the true understanding [...] a veil that just the grace of God, and not human intelligence, can remove. ${ }^{35}$ Augustine migrates from a hermeneutical towards an antihermeneutical position or, as Pier Cesare Bori said, from a 'joyful and playful (gioiosa e gio$\cos a$ )' towards a 'narrow (angusta)' hermeneutics. ${ }^{36}$ The function of allegorical expressions no longer concerns the exercise of human intellect and free interpretation. Rather, allegorical expressions have the function to discriminate and exclude, 'to throw a veil over the minds of the godless either that they may be converted to piety or shut out from a knowledge of the mysteries.' ${ }^{37}$ In conclusion, comparing the verbum in corde with an obscure allegory, Augus- 
tine understands the notion in the light of this evenemential and anti-hermeneutical perspective, which finds its roots in the doctrine of the gratuitous election to salvation.

\section{Gadamer Interpreter of Augustine's verbum in corde}

Gadamer's interest towards Augustine is focused on three topics: time, hermeneutics and language. Through his notion of time as 'form of human experience' and 'place of truth', Augustine would have somehow surpassed the Greek metaphysics of presence. ${ }^{38}$ In the De doctrina christiana, Gadamer has seen a certain hermeneutical awareness, a methodological conscience and the effort to mediate between Old and New Testament. It is precisely in this effort of mediation that the German philosopher recognizes a central task for hermeneutics:

We have seen that the goal of all attempts to reach an understanding is agreement concerning the subject matter. Hence the task of hermeneutics has always been to establish agreement where there was none or where it was disturbed in some way. The history of hermeneutics confirms this if, for example, we think of Augustine, who sought to mediate the Gospel with the Old Testament. ${ }^{39}$

Through the Augustinian theory of language, and in particular thanks to the notion of verbum in corde, Gadamer pretends to fight the Western oblivion of language. According to some interpreters, however, the German philosopher has used the notion as an instrument. Sebastiano Vecchio, for instance, stated that the overabundance of meaning that hermeneutics attributes to the language is completely extraneous to Augustine. ${ }^{40}$ Johannes Brachtendorf said that not one of the elements that for Gadamer contributes to the rehabilitation of language, is present in the Augustinian theory, neither its original character, nor its processuality, nor its immediate relation with reality. Since the verbum in corde represents the essence of things, it cannot be used to overcome the metaphysics of presence. ${ }^{41}$ According to Giorgio Santi, privileging a hermeneutics of discourse over a hermeneutics of the verbum mentis, Gadamer hinders any truthful understanding of Being. ${ }^{42}$ Alfred Schindler's position is more tempered. On the one hand, he says, in Augustine's theology of the Word, the language's devaluation that Gadamer refuses is present. On the other hand, however, for Augustine, human will has a central role in the generation of the word (generatio verbi), and this activity is similar to the evenemential character that Gadamer attributes to the language. ${ }^{43}$

It is true that in several passages of the paragraph Sprache und verbum, Gadamer, reflecting on the Augustinian verbum in corde, seems to be concerned with the national and spoken 
languages, as when he writes that 'the external word and with it the whole problem of the variety of languages, was explicitly devalued by Augustine, though he still discusses it. ${ }^{44}$

Nevertheless, the German philosopher is aware that for Augustine 'the fact that the verbum is spoken differently in different languages (Sprache), however, means only that it cannot reveal itself through the human tongue (Zunge) in its true being. ${ }^{45}$ Similarly, in an interview given to Jean Grondin in 1996, Gadamer confirms that 'the multiplicity of languages must not represent an insurmountable barrier for hermeneutics, since all languages can be learned.'46 The notion of verbum in corde does not concern the multiplicity of human languages, but rather the 'infinite task', which 'lies in the experience of the limit of the word as such. ${ }^{47}$

According to other interpreters, Gadamer has simply accomplished Augustine's intentions. Reasoning on the analogy of proportion between the Word in God and the incarnate Word on the one hand, the inner and the spoken word in man on the other hand, Gadamer would have fulfilled the partial rehabilitation of language already existing in the Augustinian theology of verbum. Jochem Hennigfeld stated that Gadamer has been the first to show that the Christian notion of incarnation is a valid alternative to the instrumental conception of language. ${ }^{48}$ For Johann Kreuzer, therefore, Augustine's inner word does not limit the language in interiority, but rather opens it to its own most possibility of concreteness. Gadamer would have been able to recognize in this notion a non-instrumental conception of language that is particularly useful for his hermeneutics. ${ }^{49}$ According to Graziano Ripanti, Augustinian theory of language is at the same time Platonic and Biblical. From the former, Augustine would have inherited the idea of the mutability of being and of human action, and hence the consequent devaluation of language. From the latter, he would have inherited the idea that revelation is given through divine signs (signa divinitus data), and hence the resulting partial rehabilitation of language. The signs of the Scriptures are an aid to human fallibility, just as Christ, becoming flesh, became a remedy for our wounds. Through the theory of the signa divinitus data, Augustine understands the 'deep connection between word and incarnation in the unity of the mistery of Christ. ${ }^{50}$ Rehabilitating the notion of verbum in corde, Gadamer refers precisely to this Biblical root, and in particular to the analogy of proportion which is implied.

It is true, here too, that in several passages of the paragraph Sprache und verbum, Gadamer seems concerned with the analogy of proportion, as when he says that 'exegesis interprets the speaking of the word to be as miraculous as the incarnation (Fleischwerden) of God. ${ }^{51} \mathrm{Nev}-$ ertheless, few lines below the German philosopher points out that: 
The great miracle of language lies not in the fact that the Word becomes flesh and emerges in external being, but that that which emerges and externalizes itself in utterance is always already a word. That the Word is with God from all eternity is the victorious doctrine of the church in its defense against subordinationism, and it situates the problem of language, too, entirely within inner thought. ${ }^{52}$

In other words, the mystery of Trinity is mirrored in the language insofar the word is nothing by itself, and does not seek to be anything: it has its being in its revealing. 'Exactly the same thing, Gadamer says, is true of the mystery of the Trinity. Here too the important thing is not the earthly appearance of the Redeemer as such, but rather his complete divinity.' ${ }^{53}$ Similarly, in a dialogue of 1998 with Gudrun Kühne-Bertram and Frithjof Rodi on the logical hermeneutics of Georg Misch and Hans Lips entitled Die Logik des verbum interius, Gadamer stresses that the important thing in what Germans call 'linguisticity (Sprachlichkeit)', and Sto-

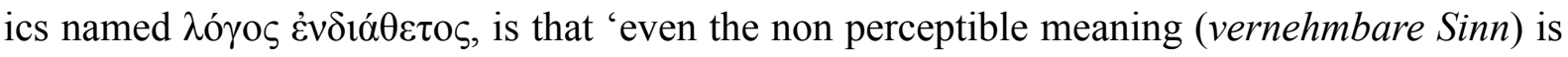
already logos.' 54

Now, my thesis here is that in his rehabilitation of the verbum in corde Gadamer neither betrayed nor accomplished Augustine's intentions. Rather, the German philosopher has properly understood the notion. In an article published in 1993, Europa und die Oikoumene, Gadamer states that 'the descent of the Son from the Father' is similar to the 'emerging when something arrives to the language. ${ }^{55}$ To define the notion of verbum in corde, Gadamer does not use in this context the distinction between inner and outer word, but the Augustinian concept of distentio animi. ${ }^{56}$ The German philosopher defines elsewhere such a concept as the 'tension of the soul towards the future and, ultimately, towards the liberation from temporality through the intervention of the divine grace. ${ }^{57}$

In one of the interviews given to RAI Italian television, Gadamer clearly explains the reason of his interest in the De Trinitate:

I would like to recall, however, that Augustine has written over 15 books on the Trinity - the De Trinitate, which is his masterpiece. The Confessions are without any doubt the most famous work of world literature (I am sure), but for philosophers these 15 books on the Trinity represent the core of his thought. How so? How is it possible? On this point it is absolutely necessary to be clear: Christianity would not be what it is, if it would be a doctrine that can be taught, if the requirement of faith would not be lived just as faith, i.e. as a gift. ${ }^{58}$ 
Gadamer seems to have perfectly understood, in sum, that Augustine's 'analogy' concerns just the Word of God and the inner word in man, the presence of the former and the latter as its effect on the human soul. Augustine's 'spaeculum (mirror)' is, in other terms, closed to Gadamer's 'speculative (spekulative)' structure of language, which has nothing to do with Hegel's description of speculative thought in his analysis of the logic of the philosophical proposition. Rather, it concerns the 'realization of meaning (Vollzug der Rede)' and the 'event of speech (Geschehen der Rede)', two expressions that Gadamer borrows from the 'first' Heidegger, but understands according to the the subjective genitive of the 'second' Heidegger. 59

Before entering the third part of the article, there is still a point that must be clarified, i.e. the fact that in the paragraph Sprache und verbum Gadamer discusses much more Thomas Aquinas'verbum mentis than Augustinian verbum in corde. According to Dominic Kaegi, when Gadamer treats the topic, he has not in mind the Augustinian relation between inner and outer word, as Jean Grondin states, but rather the Thomasian relation between word and thing. ${ }^{60}$ Far from being an extrinsic remark, this sounds as an objection that can invalidate the entire article, along with the hundreds of pages that have been written on Gadamer's rehabilitation of the Augustinian notion of inner word. Now, it is true that when the German philosopher explains what hermeneutics can learn from the concept of inner word, he says that 'a person who thinks something - i.e., says it to himself - means by it the thing that he thinks. His mind is not directed back toward his own thinking [...]. Thus the word is not the expression of the mind but is concerned with the similitudo rei.' ${ }^{61}$ Yet according to Gadamer, this similitudo has to be founded in its turn on the evenemential character of the word: 'Scholastic thought is not content with viewing concept formation as simply the reflection of the order of things.' 62 Hence, Gadamer accepts Aquinas' ordinary adaequatio but subordinates it to the Augustinian extraordinary presence - which is in-adaequatio - of the Word in the human soul. For this reason, Grondin's position seems reasonable, as he affirms that the interpretation of the inner word as a foundational instance beyond all dialogue is more Augustinian than Thomasian, and brings more justice to the Gadamerian hermeneutical project. Maybe Gadamer had some other elements in mind, too, 'but I am sure to follow him, he says, connecting the original phenomenon of hermeneutics [...] to the Augustinian notion of inner word. ${ }^{63}$

\section{Gadamer's verbum in corde}


For Ulrich Duchrow, 'it is surprising to see the extent to which Gadamer is ready to draw conclusions about the philosophy of language and ontology from Christology, though without considering the theological question further.' ${ }^{64}$ Therefore, Gadamer would have improperly used some important dogmatic notions for its philosophical purposes. In my opinion, by contrast, when Gadamer treats the verbum in corde, he is consciously assuming a position which is closed to the early dialectical theology of the protestant theologian Karl Barth and to its Pauline and Lutheran sources. In these theological reflections, the German philosopher has found a mirror of his philosophical hermeneutics, which can be considered the result of a short circuit between the existential and hermeneutical approach of the 'first', and the evenemential and anti-hermeneutical thought of the 'second' Heidegger. Notoriously, the late Heidegger gives up with hermeneutics in the proper sense. In Unterwegs zur Sprache, in the dialogue between a Japanese and an Inquirer, he still uses the term, but he states that 'hermeneutics means not just the interpretation but, even before it, the bearing of message and tidings. ${ }^{96}$ The language is not much a dialogue, but rather a silent listening of Being: 'But language is monologue. This now says two things: it is language alone which speaks authentically; and, language speaks lonesomely.'66

Heidegger seems aware of the radical incompatibility between his early and his late thought. On the contrary, Gadamer defends the dialogic character of language but, in the meantime, he confirms to have been radically fascinated by the evenemential thought of the 'second' Heidegger, as he said in an interview given to Italian interpreter Adriano Fabris in 1982. ${ }^{67}$ Of course, there are many passages of Wahrheit und Methode which are not extraneous to the personal perspective I am going to suggest in the conclusion of this article. This is the case, for instance, of the chapter devoted to the hermeneutical relevance of Aristotle, where Gadamer discusses the problem of the applicatio. These parts are perfectly coherent in themselves. Yet, the question here is how it is possible to articulate the dialogical aspect of his thought with the evenemential one. Far from being a partial objection to Gadamer's philosophy, I would say that partial is any perspective that considers his hermeneutics simply as a philosophy of the dialogue.

If on a philosophical point of view, Gadamer's position appears as quite paradoxical, on a theological point of view, instead, he assumes a more coherent perspective. His use of the

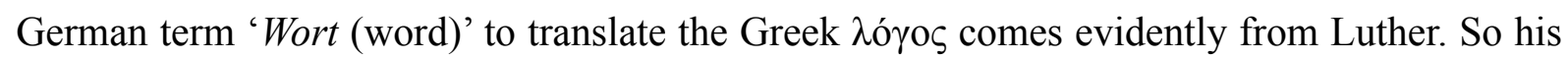
interest into Augustine's notion of verbum in corde is explained as well, since 'when Luther 
translates the logos of the Prologue of the Gospel of John as 'Wort', he takes up the whole theology of the word, which goes back, at least, to the interpretations that St. Augustine gave of the Trinity.' ${ }^{98}$ In the aforementioned interview to RAI Italian television, Gadamer recalls that

[...] In the years when I was a student in Marburg (in the Protestant Marburg of the Lutheran church) and I attended the first university in the history of the Lutheran Reformation, there was an excellent library of philosophical texts. The Middle Age was represented by Augustine - nothing else! The modern era began with Galileo - nothing else! All that stood between Augustine and Galileo - Thomas, Duns Scotus, and more - was considered 'Catholic.' ${ }^{69}$

In particular, the German philosopher is fascinated by the notion of grace. As he states in an article published in 1964, 'the task that Christianity assigns to hermeneutics is to ponder the strangeness (Fremdheit) and bewilderment (Befremdung) that dwells in the Christian message as such. This culminates in the attempt to think of redemption and faith as a divine grace in all respects, so that all capacity and all merit loose value. ${ }^{70}$ Gadamer appreciates the Protestant religious language to the extent that it is opened to an announcement, which 'goes against all human expectations. ${ }^{71}$ For this reason, in Wahrheit und Methode, it is pointed out that "certainly preaching too is concerned with interpreting a valid truth, but this truth is proclamation; and whether it is successful or not is not decided by the ideas of the preacher, but by the power of the word itself, which can call men to repentance even if the sermon is a bad one. ${ }^{72}$ In a text published in French in 1977, Herméneutique et théologie, Gadamer finally states that

\footnotetext{
The precondition of accepting the Christian message consists of opening the eyes to the experience of the divine, in a general sense. The conflict between law and grace remains essential. The idea of a dominant knowledge or technique [...] is the inherent basis of all human beings. In the field of theology, however, it remains the biggest obstacle in the acceptance of the promise of the gospel, namely the opening to grace. $^{73}$
}

This passage sounds really Barthian. ${ }^{74}$ To say the truth, however, Barth is named just once, in a marginal footnote, in Wahrheit und Methode. The mention concerns Karl Barth's reflections on 'Feuerbach's reversal of the imago dei thesis of Genesis': 'This anthropological reversal and reinterpretation of religious experience, which became current in the nineteenth century, arises from the same subjectivism that lies at the basis of modern aesthetic thought.' 75 This brief statement is important, however, for at least three reasons. 
First of all, because Gadamer opposes Barth's antisubjectivism to modern aesthetics, which is an object of criticism in the first part of Wahrheit und Methode. For Gadamer, beauty is not a matter of personal taste, not even that of the romantic genius. Rather, true beauty is universal, and 'the world of the work of art, in which play expresses itself fully in the unity of its course, is in fact a fully transformed world. In and through it everyone recognizes that that is how things are. ${ }^{76}$ The same criticism is at the core of the second and third part of the Gadamerian opus magnum. In the name of the 'wirkungsgeschichtliche Bewusstsein', which I propose to translate as 'conscience of the work of history', the German philosopher rehabilitates authority and tradition against Enlightenment's critics of prejudice: 'the fundamental prejudice of the Enlightenment is the prejudice against prejudice itself, which denies tradition its power.' 77 In the aforementioned interview with A. Fabris, Gadamer affirms that the conscience of the work of history has nothing to do with the traditional concept of conscience, but rather with the late Heideggerian notion of Being. ${ }^{78}$ As we have seen in the course of this article, the third part of Wahrheit und Methode is devoted to overcoming the instrumental notion of language. The brief reference to Karl Barth, thus, is mirrored the Gadamer's purpose to elevate hermeneutical experiences to the rank of truth events.

Secondly, the reference is important since Barthian religious antisubjectivism is opposite Protestant liberal theology, whose founder has been Schleiermacher. According to Gadamer, as Heidegger had already stated in his 1923 seminar Ontologie. Hermeneutik der Faktizität, Schleiermacher has privileged the technical and psychological dimension of hermeneutics. Hence, he has exalted the subjective dimension of interpretation, i.e. the intentions of the author, to the expense of the claim for truth of the text - the thing of the text. However, Schleiermacher did not accomplish the technicist and psychologist orientation of the historical school and the romantic hermeneutics. His hermeneutics is still oriented toward the dogmatic interest for specific texts: 'his hermeneutical theory was still a long way from a historiology that could serve as a methodological organon for the human sciences. Its goal was the exact understanding of particular texts.' 79 This is, after all, the intrinsic paradox of the entire liberal theology's tradition. On the one hand, it aims to display the universal character of the proclamation. On the other hand, however, it remains within the specific proclamation of Jesus Christ. Liberal theology, then, cannot realize its proper claim for universality. Gadamer's critics to the Schleiermacherian hermeneutics can be understood as a consequence of the critics to the self-consciousness of faith, which is, according to him, the dogmatically dangerous ba- 
sis of Schleiermacher's theology. ${ }^{80}$ For this reason, in one of the sporadic references to Barth, Gadamer affirms that 'despite the general aversion to methodological reflection, [the Römerbrief] is a sort of interpretation manifesto. ${ }^{81}$ A quite strange statement, to tell the truth, since one could say that it is precisely the lack of method that, for Gadamer, makes Karl Barth's exegesis a genuine hermeneutical practice: 'after all, he says, I do not propose any method, but I just describe what it is [...] evidently I could not persuade Betti that a philosophical theory of hermeneutics, right or wrong, is not a doctrine of the method.' 82

Thirdly, the brief reference to Karl Barth in Wahrheit und Methode is important since it reminds the Gadamerian critics of Bultmann's demythologization. ${ }^{83}$ Jean Grondin, although underestimating Gadamer's 'religious dimension', has opportunely stated that according to the German philosopher, Butlmann 'has remained too close to the (transcendental) conception of understanding presented in Being and Time', and that, for this reason, 'he could not consider the thought of the last Heidegger [...]. For Gadamer, instead, this thought could have been striking for theology, since it looks for a more adequate language to the expression of the divine.' 84 According to Gadamer, in fact, Bultmann's affirmation in Glauben und Verstehen that 'the interpretation of the biblical writings is subject to exactly the same conditions as any other literature' is ambiguous. ${ }^{85}$ Theologian's interpretation, although scientific as Bultmann's demythologization pretends to be, 'must never forget that Scripture is the divine proclamation of salvation.' 86 On the one hand, Bultmann recognizes, as Heidegger did, that all interpretation presupposes a vital relation of the interpreter with the interpreted text, and a preliminary relation with the thing (Sache), which is communicated through the text. On the other hand, Bultmann does not see that such a pre-comprehension is not the result of a scientific process of interpretation, but rather is 'presupposed as already given'. The prerequisite, which is opened to interpretation, consists of being touched by the problem of God. And such a prerequisite is not given by the simple fact of being a man, as liberal theology explicitly suggests, and Bultmann's demythologization implicitly admits; rather, Gadamer affirms, 'it is first from God - i.e. from faith.' ${ }^{87}$ Only the grace of God, which is a truth event, opens for the German philosopher the space for genuine interpretation.

The Catholic Church, with its predilection for the works, would not have understood, according to Gadamer, this principle of ontological hermeneutics. Bultmann, in his turn, has forgotten that the demythologization is already enclosed in this first prerequisite, exactly as Heideggerian analytics of the Dasein is enclosed into the ontological question on the sense of 
Being. As interpreter Giovanni Moretto has suggested, 'Gadamer call than Bultmann back to the Protestant orthodoxy, i.e. to a theology that, even if does not consider anymore, as Luther did, the human reason as something diverted and prostituted [...], still deny the possibility of an interpretation of Biblical texts external to the context of faith. ${ }^{88}$

In conclusion, I can say that the Gadamerian use of the Augustinian verbum in corde, properly understood as the consequence of the Word- and Truth-event of God on men, is the consequence of such a radical notion of grace, which is, in its turn, the adequate paradigm of the anti-methodological and anti-liberal ontological hermeneutics of Gadamer.

\section{Conclusion}

In the first section, I have demonstrated that the Augustinian notion of verbum in corde is an innovation with regards to both the 'Greek' and the 'Biblical' tradition. The bishop of Hippo is not asmuch interested into the linguistic structure of the human mind, nor in the relation between the inner and outer word, and its similitude with the Word of God. Rather, Augustine is concerned with the efficacy of the Word of God on men: the verbum in corde is the consequence of a Word- and Truth- event. If there is a partial rehabilitation of exteriority, as some interpreters have suggested, this is just a consequence of this more radical statement. In the second section, I have demonstrated that, through his rehabilitation, Gadamer did not misunderstand, nor accomplish Augustine's intentions. Rather, the German philosopher has properly understood the Augustinian notion of verbum in corde as a matter of faith, i.e. the consequence of a gift that cannot be returned. ${ }^{89}$ In his perspective, the importance of the notion does not much reside in the rehabilitation of the spoken and national languages. More profoundly, the verbum in corde concerns the unique Word, which is behind - and supports - all genuine words. In the third section, I have suggested that Gadamer finds in the Augustinian notion a paradigm for both its philosophical and theological insights. Concerning the former, the German philosopher, although defending the dialogicity of language, has always been fascinated by the evenemential character of the late Heidegger's thought. Concerning the latter, he has explicitly accused Bultmann's demythologization of being 'human, all too human', and he has implicitly praised Barth's dialectical theology.

Now, for what I have demonstrated in these pages, Jean Grondin's hypothesis, according to which the verbum in corde is a paradigm for hermeneutics and a privileged point of view to test its effectiveness, can be considered valid. Yet, for the same reason, it is possible to dis- 
agree with him at least twice. First of all, because the verbum in corde does not set in motion, as the French interpreter affirms, any circularity between the said and the unsaid. The Augustinian notion does not much suggest that 'there is something like a dialogue 'behind' or better 'with' every enunciation. ${ }^{90}$ Rather, the verbum in corde suggests that, behind all true dialogue, there is just a monologue. Hence, the notion does not charge the language of its essential hermeneutical circularity, but it seems rather to 'anesthetize' it. The verbum in corde, therefore, makes hermeneutics somehow ineffective. Secondly, because it is not true that the Augustinian notion represents a paradigm for all hermeneutics aiming at truth and universality. In Paul Ricoeur, for instance, truth and method do not represent any alternative. ${ }^{91}$ Moreover, I believe that hermeneutics should now question its own concepts of meaning, truth and being without fearing to be considered nihilistic. Between the substantialization of meaning and the Nietzschean formula 'there are no facts, only interpretations', there is room for a 'lesser hermeneutics', which does not consider understanding as a Meaning-, Truth- or Beingevent, but rather as the always-renegotiable conviction of having reached a little bit of meaning, truth or beings.

\section{Notes}

1. See Grondin, 'Gadamer und Augustin'; L'universalité de l'herméneutique; 'L'universalité de l'herméneutique et de la réthorique: ses sources dans le passage de Platon à Augustin dans Vérité et Méthode'.

2. See Oliva, Das innere verbum; Artos, The inner Word.

3. In Wahrheit und Methode, Gadamer referers just once to the 'verbum cordis' - as he calls it - of De Trinitate $\mathrm{XV}, 10-15$.

4. Gadamer, Wahrheit und Methode, 359 (Truth and Method, 348).

5. Ibid., 361 (351).

6. Koch, 'Le verbum in corde', 3.

7. For the notion of inner word in Luther, see zur Mühlen, Nos extra nos; Beutel, In dem Anfang, 372-406. For these authors, Luther has never completely renounced the classical distinction between inner and outer word. Rather, he has radically reinterpreted it in light of the distinction between litera and spiritus. In other words, Luther has not been concerned with the ontical or ontological status of the word, but with its (theological) effectiveness (Wirksamkeit/Wirkungscarachter).

8. See Romele, 'La parole efficace chez Gerhard Ebeling et Paul Ricœur'.

9. For Plato see Thaet., 189e, Phil. 38d-e and Soph., 263e; for Aristotle see An. Post. 10, 76b and Cat. 6, 4b 3435. 
10. On the origins of the distinction see Pohlenz, 'Die Begründung der abendländischen Sprachlehre; Mühl, 'Der

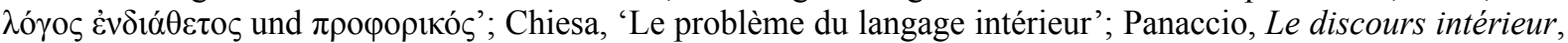
58-59. According to M. Pohlenz, the distinction goes back to the mid-second century B.C., at the time when Carneades was head of the Academy, in the context of the debate between Stoics and Academicians on the rationality of animals, and it is not born among Stoics but among Academicians. For M. Mühl, the distinction goes back to the same debate, but it already existed in fourth century B.C., at the time of the academician Theofrastus, and it is born among the Stoics. C. Chiesa places the origins of the distinction more generally at the time of the debate on the difference between humans and animals that opposed the Stoics to Plato's disciples Arcesilaus and Carneades. Finally, C. Panaccio criticizes the general identification of the Dogmaticians mentioned by Sextus Empiricus in Adv. Math. VIII, 275-276 with the Stoics. According to him, referring to the Dogmaticians, Sextus Empiricus means all skeptical philosophers, whether Stoic, Epicurean, Peripatetic and Platonic, i.e. all those philosophers who recognized a form of existence, sensible, intelligible or other, to the signs.

11. In his Dialogue with Trypho $(61,2)$, Justin tried to explain the Christian idea of $\lambda$ ó $\gamma$ os comparing it with the duality of the human word: 'for when we give out some word, we beget the word; yet not by abscission, so as to

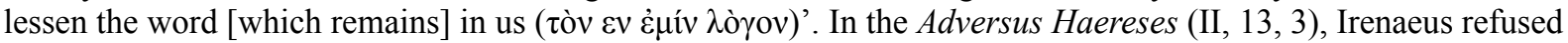
this comparison between the Word of God and the human word: 'By their manner of speaking, they ascribe those things which apply to men to the Father of all, whom they also declare to be unknown to all'. The distinction has been condemned during the Council of Sirmium, as reported in Athanasius' De Synodis II, 49: 'If someone says

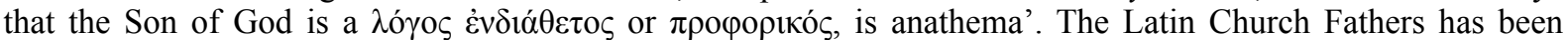

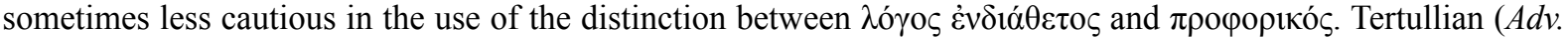
Prax., 5) affirmed: "Observe, then, that when you are silently conversing with yourself, this very process is carried on within you by your reason, which meets you with a word at every movement of your thought, at every impulse of your conception. [...] Now how much more fully is all this transacted in God, whose image and likeness even you are regarded as being [...]'. One century later, Lanctantius (Div. Inst. IV, 9) stated that 'the Greeks speak of Him as the $\lambda$ ójos, more befittingly than we do as the word, or speech: for Logos signifies both speech and reason, inasmuch as He is both the voice and the wisdom of God'. Ambrose, the Bishop of Milan who baptized Augustine, has similarly condemned the use of the distinction in Fid. IV, 7, 72: 'It is only the Word of God,

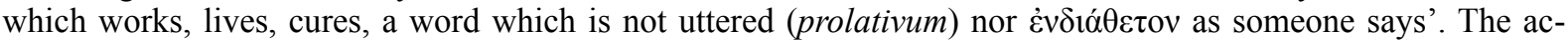
cepted superiority of the inner over the spoken word risked in fact to undermine the dogma of consubstantiality. For the rehabilitation of the Stoic distinction in Christianity, see Bavaud, 'Un thème augustinien'.

12. Augustine, De dialectica, 5.

13. Augustine, De magistro IV, 9.

14. Ibid. IV, 8.

15. Augustine, Epistulae ad Romanos inchoata, 23, 8.

16. Ibid.

17. Augustine, De doctrina christiana I, 13, 12.

18. On this point see also Watson, 'St. Augustine and the Inner Word'.

19. Ripanti, Agostino teorico dell'interpretazione, 30. The most part of the contemporary interpretations of the De Magistro has been focused, in fact, on the first part of the dialogue, devoted to the language - see, for instance Wittgenstein's critique at the beginning of his Philosophische Untersuchungen. An exception is represented by Paul Ricœur, 'Le «soi mandaté»'. See also Bermon, La signification et l'enseignement; Madec, 'Le Christ Maître intérieur'. These authors include the Augustinian dialogue in the tradition of Christ as inner teacher. For the figure of Christ as inner teacher in the New Testament and among the apologists of the first and second century, see Normann, Kristos Didaskalos.

20. Augustine, De Trinitate VIII, 6, 9.

21. Ibid. IX, 10, 15 .

22. Ibid. IX, $4,5$.

23. Ibid. VIII, 6, 9.

24. Marion, Au lieu de soi, 121.

25. Augustine, De Trinitate XI, 2, 2.

26. Ibid. XI, 3, 6 .

27. Ibid.

28. Ibid. XII, 2, 2.

29. Ibid. XV, 3, 5 .

30. Ibid. XV, 10, 19.

31. Augustine, De Trinitate XV, 9, 15.

32. Pépin, Mythe et Allégorie, 247. 
33. Todorov, Symbolisme et interprétation, 104.

34. Augustine, De doctrina christiana II, 6, 7.

35. Lettieri, L'altro Agostino, 177. For a critique to Lettieri, see Cipriani, 'L'altro Agostino'.

36. See Bori, 'Figure materne'.

37. Augustine, De doctrina christiana IV, 8, 22. On the concept of secrecy and the principle of exclusion in the New Testament, see Kermode, The genesis of secrecy.

38. Gadamer, Das Rätsel der Zeit, 138. According to Jean Grondin, Gadamer has partially devoted to Augustine's notion of time a seminar in winter semester 1940, Übungen zum Problem der Zeit. See Grondin, Gadamer. Eine Biographie, 393.

39. Gadamer, Wahrheit und Methode, 297 (292).

40. Vecchio, Le parole come segni, 51.

41. Brachtendorf, Die Struktur, 313.

42. Santi, 'Interiorità ermeneutica, 188.

43. Schindler, Wort und Analogie, 240.

44. Gadamer, Wahrheit und Methode, 424 (419-420).

45. Ibid.

46. Gadamer, 'Dialogischer Rückblick', 287.

47. Ibid.

48. Hennigfeld, 'Verbum-Signum', 263.

49. Kreuzer, Pulchritudo, 243.

50. Ripanti, Agostino teorico dell'interpretazione, 33.

51. Gadamer, Wahrheit und Methode, 424 (419).

52. Ibid.

53. Ibid., 425 (420).

54. Gadamer, Kühne-Bertram, and Rodi, 'Die Logik des verbum', 25.

55. Gadamer, 'Europa und die Oikumene', 272.

56. Oliva, Das innere Wort, 83-84.

57. Gadamer, 'Das Rätsel der Zeit', 138.

58. Gadamer, Agostino.

59. Gadamer, Wahrheit und Methode, 472 (464).

60. Kaegi, 'Was heisst und zu', 116-132.

61. Gadamer, Wahrheit und Methode, 430 (425).

62. Ibid., 431 (426).

63. Grondin, 'L'universalité de l'herméneutique', 189-190.

64. Duchrow, Sprachverständnis, 146.

65. Heidegger, Unterwegs zur Sprache, 115; On the way to..., 29.

66. Ibid., 254 (134).

67. Gadamer, 'Interpretazione e verità', 167.

68. Gadamer, 'Von der Wahrheit', 37.

69. Gadamer, Agostino.

70. Gadamer, ‘Ästetische und religiöse Erfahrung', 150.

71. Ibid.

72. Gadamer, Wahrheit und Methode, 336 (326).

73. Gadamer, 'Herméneutique et théologie', 397.

74. Some further considerations should be done about the evolution of Barthian theology after the second edition of the Römerbrief. Notoriously, H. U. von Balthasar sees in the Anselmbuch a turning point in the theology of the Protestant theologian. The analogia fidei does not eliminate the analogia entis, but presupposes it. On the contrary, according to authors such as B. McCormack and, more recently, K. L. Johnson, Barth never called into question the supremacy of the Lutheran principle of the sola gratia. At the time of the Dogmatik, the analogia entis entails a certain participatio entis, a similarity between men and God, which is nevertheless just a consequence of the continuous event of the automanifestation of God to men. See Johnson, Karl Barth.

75. Gadamer, Wahrheit und Methode, 148 (137).

76. Ibid., 118 (112). 
77. Ibid., 275 (273).

78. Gadamer, Verità e interpretazione, 168.

79. Gadamer, Wahrheit und Methode, 201 (195).

80. Moretto, La dimensione religiosa, 112.

81. Gadamer, 'Hermeneutik und Historismus', 391.

82. Ibid., 394-395.

83. For a similar critics to Bultmann see also Ricœur, 'Préface à Bultmann'.

84. Grondin, 'Gadamer et Bultmann', 126.

85. Gadamer, Wahrheit und Methode, 336 (327).

86. Ibid..

87. Ibid., 337 (327).

88. Moretto, La dimensione religiosa, 98-99.

89. Jean-Luc Marion has well shown the incompatibility of donation and interpretation. See, for instance, Marion, Dieu sans l'être, 212.

90. Grondin, L'universalité de l'herméneutique, 38.

91. See Ricoeur, 'La fonction herméneutique'. 


\section{Bibliography}

Artos, John. The inner Word in Gadamer's Hermeneutics. Notre Dame: University of Notre Dame Press, 2009.

Augustine. Against the Academicians and The Teacher, translated by Peter King. Indianapolis: Hackett Publishing Company, 1995.

Augustine. Augustine on Romans: Propositions from the Epistle to the Romans; Unfinished Commentary on the Epistle to the Romans, translated by Paula Fredriksen Lands. Chico, CA: Scholars Press, 1982.

Augustine. On Christian Doctrine, translation from Select Library of Nicene and Post-Nicene Fathers. http://faculty.georgetown.edu/jod/augustine/ddc.html. Accessed October 22, 2014.

Augustine. On Dialectic, translated by James Marchand. http://faculty.georgetown.edu/jod/ texts/dialecticatrans.html. Accessed October 21, 2014.

Augustine. On the Trinity, translated by Arthur West Haddan and revised by Kevin Knight. http://www.newadvent.org/fathers/1301.htm. Accessed October 21, 2014.

Augustine. "To Simplician. On various Questions." In Augustine. Earlier Writings, edited by John H. S. Burleigh, 370-406. Paperback edition. Louisville, KY: 2006.

Bavaud, Georges. "Un thème augustinien: le mystère de l'incarnation, à la lumière de la distinction entre le verbe intérieur et le verbe proféré." Revue Augustinienne, no. 9 (1963): 95101.

Bermon, Emmanuel. La signification et l'enseignement. Texte latin, traduction française et commentaire du De Magistro de Saint Augustin [The Meaning and the Teaching. Latin Text, French Translation and Commentary of the De Magistro of Saint Augustine]. Paris: Vrin, 2007. 
Beutel, Albrecht. In dem Anfang war das Wort. Studien zu Luthers Sprachverständnis [In the Beginning was the Word. Studies into Luther's Language Understanding]. Tübingen: Mohr Siebeck, 1991.

Bori, Pier Cesare. "Figure materne e Scrittura in Agostino." Annali di storia dell'esegesi 9, no. 2 (1992): 397-420.

Brachtendorf, Johannes. Die Struktur des menschlichen Geistes nach Augustinus. Selbstreflexion und Erkenntnis Gottes in De Trinitate [The Structure of the Human Soul according to Augustine. Self-reflection and Knowledge of God in De Trinitate]. Hamburg: Felix Meiner, 2000.

Chiesa, Curzio. "Le problème du langage intérieur chez les stoïciennes." Revue internationale de philosophie 178, 1991: 301-321.

Cipriani, Nello. "L'altro Agostino di G. Lettieri." Revue d'Etudes Augustiniennes 48, 2002: 249-266.

Duchrow, Ulrich. Sprachverständnis und biblisches Hören bei Augustin [Language Understanding and biblical Hearing in Augustine]. Tübingen: Mohr Siebeck, 1965.

Flasch, Kurt. Logik des Schreckens. Aug. von Hippo De diversis questionibus ad Simplicianum I, 2 [The Logic of the Terror. Augustine of Hippo's De diversis questionibus ad Simplicianum I, 2]. Mainz: Dieretich, 1990.

Gadamer, Hans-Georg. Agostino. http://www.emsf.rai.it/gadamer/interviste/08_agostino/ agostino.htm\#5. Accessed October 23, 2014.

Gadamer, Hans-Georg. "Ästetische und religiöse Erfahrung." In Ästethik und Poetik I: Kunst als Aussage. Gesammelte Werke 8, 143-155. Tübingen: Mohr Siebeck, 1993. 
Gadamer, Hans-Georg. "Dialogischer Rückblick auf das Gesammelte Werk und dessen Wirkungsgeschichte." In Gadamer Lesebuch [Gadamer Reader], edited by Jean Grondin, 281-295. Tübingen: Mohr Siebeck, 1997.

Gadamer, Hans-Georg. "Europa und die Oikumene." In Hermeneutik im Überblick. Gesammelte Werke 10, 267-284. Tübingen: Mohr Siebeck, 1994.

Gadamer, Hans-Georg. "Hermeneutik und Historismus." In Wahrheit und Methode II: Ergänzungen. Register. Gesammelte Werke 2, 287-424. Tübingen: Mohr Siebeck, 1986.

Gadamer, Hans-Georg. "Herméneutique et théologie." Revue des Sciences Religieuses 51 (1977): 384-397.

Gadamer, Hans-Georg. "Interpretazione e verità: colloquio con Adriano Fabris." Teoria 2 (1982): 158-175.

Gadamer, Hans-Georg. "Das Rätsel der Zeit.” In Neuere Philosophie II: Probleme. Gestalten. Gesammelte Werke 4, 119-172. Tübingen: Mohr Siebeck, 1987.

Gadamer, Hans-Georg. Truth and Method. Translated by Joel Weinsheimer and Donald G. Marshall. New York: Continuum, 2004.

Gadamer, Hans-Georg. "Von der Wahrheit des Wortes." In Ästethik und Poetik I: Kunst als Aussage. Gesammelte Werke 8, 37-57. Tübingen: Mohr Siebeck, 1993.

Gadamer, Hans-Georg. Wahrheit und Methode. Gesammelte Werke 1 [Truth and Method. Complete Works 1]. Tübingen: Mohr Siebeck, 1986.

Gadamer, Hans-Georg, Gudrun Kühne-Bertram, and Frithjof Rodi, "Die Logik des verbum interius. Hans-Georg Gadamer im Gespräch mit Gudrun Kühne-Bertram und Frithjof Rodi.” Dilthey Jahrbuch 11 (1997/1998): 19-30. 
Grondin, Jean. Gadamer. Eine Biographie [Gadamer. A Biography]. Tübingen: Mohr Siebeck, 1999.

Grondin, Jean. "Gadamer et Bultmann." In L'héritage de Hans-Georg Gadamer [The Heritage of Hans-Georg Gadamer], edited by Guy Deniau, Jean-Claude Gens, 113-131. Paris: Le cercle herméneutique, Collection Philo, 2003.

Grondin, Jean. "Gadamer und Augustin. Zum Ursprung des hermeneutischen Universalitätsanspruchs." Jahresgabe der M. Heidegger Gesellshaft 1990: 29-42.

Grondin, Jean, L'universalité de l'herméneutique [The Universality of Hermeneutics]. Paris: Vrin, 1993.

Grondin, Jean. "L'universalité de l'herméneutique et les limites du langage. Contribution à une phénoménologie de l'inapparent." Laval théologique et philosophique 53, no. 1 (1997): 181-194.

Grondin, Jean. "L’universalité de l'herméneutique et de la rhétorique: ses sources dans le passage de Platon à Augustin dans Vérité et Méthode." Revue internationale de philosophie 54 (2000): 469-485.

Heidegger, Martin. On the way to language. Translated by Peter D. Hertz. New York: Harper Collins, 1971.

Heidegger, Martin. Unterwegs zur Sprache. Gesamtausgabe XII [On the Way to the Language. Complete Works XII]. Frankfurt: Klostermann, 1985.

Hennigfeld, Jochem, "Verbum-Signum. La définition du langage chez St. Augustin et Nicolas de Cues." Archives de philosophie 54 (1991): 255-268.

Johnson, Keith L. Karl Barth and the analogia entis. London: T \&T Clark, 2010. 
Kaegi, Dominic. "Was heisst und zu welchem Ende studiert man philosophische Hermeneutik?" Philosophische Rundschau 53 (1997): 116-132.

Kermode, Frank. The genesis of secrecy: on the interpretation of narrative. Cambridge, MA: Harvard University Press, 1979.

Koch, Isabelle. "Le verbum in corde che Augustin." In Le langage mental du Moyen Age à l’Age classique, edited by Joël Biard, 1-28. Louvain-la-Neuve: Peeters, 2009.

Kreuzer, Johann. Pulchritudo. Vom Erkennen Gottes bei Augustin. Bemerkungen zu den Büchern IX, X und XI der Confessiones [Pulchritudo. On the Knowledge of God in Augustine. Annotations on the Books IX, X, and XI of the Confessiones]. München: Fink, 1995.

Lettieri, Gaetano. L'altro Agostino: ermeneutica e retorica della grazia dalla crisi alla metamorfosi del De doctrina christiana [The other Augustine. Hermeneutics and Rhetoric of the Grace from the crisis to the metamorphosis of the De doctrina christiana]. Brescia: Morcelliana, 2001.

Madec, Gulvain. "Le Christ Maître intérieur." In Lectures Augustiniennes [Augustinian Readings], 43-57. Paris: Institut d'Etudes Augustiniennes, 2001.

Marion, Jean-Luc. Au lieu de soi. L'approche de Saint Augustin [In the Place of Oneself. The Approach of Saint Augustine]. Paris: Puf, 2008.

Marion, Jean-Luc. Dieu sans l'être [God without Being]. 3rd ed. Paris: Puf, 2010.

Moretto, Giovanni. La dimensione religiosa in Gadamer [The Religious Dimension in Gadamer]. Brescia: Queriniana, 1997.

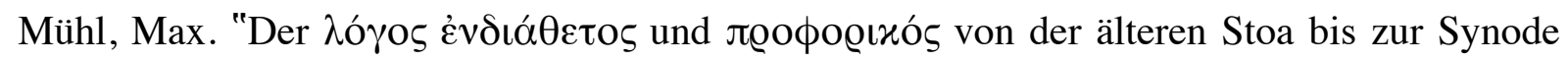
von Sirmium 351.” Archiv für Begriffgeschichte 7 (1962): 7-56. 
zur Mühlen, Karl-Heinz. Nos extra nos. Luthers Theologie zwischen Mystik und Scholastik [Nos extra nos. Luther's Theology between Mystic and Scholastics]. Tübingen: Mohr Siebeck, 1972.

Oliva, Mirela. Das innere verbum in Gadamers Hermeneutik [The inner word in Gadamer's Hermeneutics]. Tübingen: Mohr Siebeck, 2009.

Normann, Friederich. Kristos Didaskalos. Die Vorstellung von Christus als Lehrer in der christlichen Literatur des ersten und zweiten Jahrhunderts [Kristos Didaskalos. The image of Christ as a Teacher in the Christian literature of the First and the Second Century]. Münster: Aschendorff, 1967.

Panaccio, Claude. Le discours intérieur. De Platon à Guillaume d'Ockham [The Inner Speech. From Plato to William of Ockham]. Paris: Seuil, 1999.

Pépin, Jean. Mythe et Allégorie [Myth and Allegory]. Paris: Aubier, 1953.

Pohlenz, Max. "Die Begründung der abendländischen Sprachlehre durch die Stoa." Kleine Schriften I [Small Writings I], 39-86. Hildeshein: Georg Olms, 1965.

Ricoeur, Paul. "La fonction herméneutique de la distanciation." Du texte à l'action [From Text to Action], 113-131. Le Seuil: Paris, 1986.

Ricœur, Paul. "Préface à Bultmann.” Le conflit des interprétations [The Conflict of Interpretations], 373-392. Paris: Le Seuil, 1969.

Ricœur, Paul. "Le «soi mandaté». Oh my prophetic soul!." Amour et justice [Love and Justice], 75-110. Seuil: Paris, 2007.

Ripanti, Graziano. Agostino teorico dell'interpretazione [Augustine Theorist of Interpretation]. Brescia: Paideia, 1980. 
Romele, Alberto, "La parole efficace chez Gerhard Ebeling et Paul Ricœur." Revue de théologie et de philosophie 144/4 (2012): 305-318.

Santi, Giorgio. "Interiorità ermeneutica: l'Agostino di Gadamer.” In Ripensare Agostino: interiorità e intenzionalità [Rethinking Augustine. Interiority and Intentionality], edited by Luigi Alici, Remo Piccolomini, and Antonio Pieretti, 183-191. Roma: Institutum Patristicum Augustinianum, 1993.

Schindler, Alfred. Wort und Analogie in Augustinus Trinitätslehre [Word and Analogy in Augustine's Doctrine of Trinity]. Tübingen: Mohr Siebeck 1965.

Todorov, Tvetan. Symbolisme et interprétation [Symbolism and Interpretation]. Paris: Seuil, 1978.

Vecchio, Sebastiano. Le parole come segni. Introduzione alla linguistica agostiniana [The Words as Signs. Introduction to the Augustinian Linguistic]. Roma: Novecento, 1994.

Watson, Gerard. "St. Augustine and the Inner Word: the philosophical background". Irish Theological Quarterly 54 (1988): 81-92.

Alberto Romele has received a Ph.D. from the University of Verona (Italy) in 2011. In 2012 he has been 'Oratoire-Ricoeur' fellow at the Fonds Ricoeur of Paris (France). Currently he is post-doc researcher of the FCT (Fundação para a Ciência e a Tecnologia) at the Institute of Philosophy of the University of Porto (Portugal) and visiting researcher at the COSTECH Laboratory of the University of Technology of Compiègne (France). His researches focus on the history of philosophical and theological hermeneutics on the one hand; on the other hand, he is interested into the application of hermeneutical theories to the domain of the ICTs (Information and Communication Technologies).

romelealberto@gmail.com 